Peter Bartelmus*

\title{
Dematerialization and Capital Maintenance: \\ Two Sides of the Sustainability Coin
}
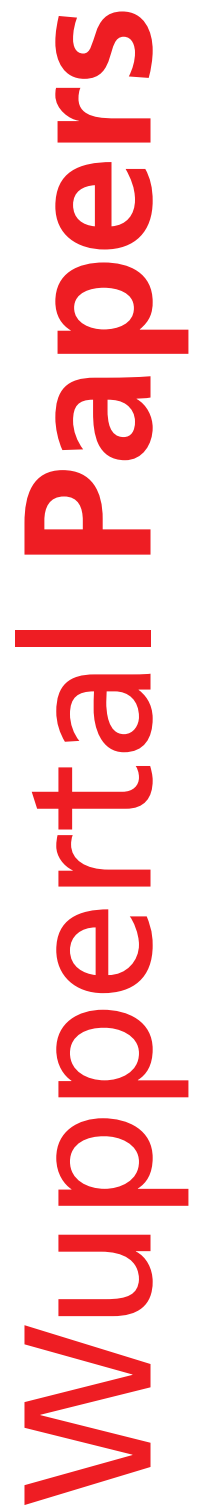

No. 120 - January 2002

ISSN 0949-5266 
Wuppertal Papers are scientific working papers of a preliminary character aimed at promoting scientific discourse. Comments and contributions to the discussion are encouraged by the authors. As a report from a research process not yet concluded, the contents do not necessarily reflect the opinions of the Wuppertal Institute.

Slight deviations between the printed version and the PDF version are possible. For example, blank pages have been omitted in this PDF document. Therefore, if you are quoting from the PDF version, we suggest that you indicate this in brackets: "PDF version".

Wuppertal Institute for Climate, Environment and Energy

Division for Material Flows and Structural Change

Peter Bartelmus

Döppersberg 19

42103 Wuppertal

Tel.: 0202-2492 -132

Fax: 0202-2492-138

E-Mail: peter.bartelmus@wupperinst.org

http://www.wupperinst.org

* Comments and suggestions by Raimund Bleischwitz are gratefully acknowledged 


\section{Contents}

Abstract $\ldots \ldots \ldots \ldots \ldots \ldots \ldots \ldots \ldots \ldots \ldots \ldots \ldots \ldots \ldots \ldots \ldots \ldots \ldots \ldots \ldots \ldots, \quad 4$

1 Sustainable development - the great hypocrisy $\ldots \ldots \ldots \ldots \ldots \ldots$

2 Unveiling wealth: measuring material throughput and

natural capital consumption $\ldots \ldots \ldots \ldots \ldots \ldots \ldots \ldots \ldots \ldots \ldots \ldots, \quad 7$

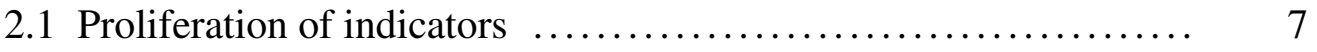

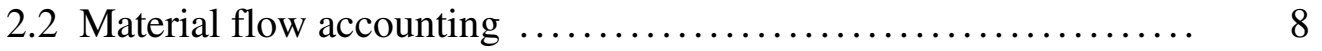

2.3 Greening the national accounts $\ldots \ldots \ldots \ldots \ldots \ldots \ldots \ldots \ldots \ldots . . \ldots \ldots$

3 Dematerialization versus capital maintenance $\ldots \ldots \ldots \ldots \ldots \ldots . \ldots 12$

3.1 Dematerialization: attaining ecological sustainability $\ldots \ldots \ldots \ldots . .12$

3.2 Economic sustainability: maintaining growth and welfare ........ 14

3.3 A physical-monetary dichotomy $\ldots \ldots \ldots \ldots \ldots \ldots \ldots \ldots \ldots \ldots \ldots . \ldots \ldots \ldots \ldots$

4 Germany: a sustainable economy? ........................ 18

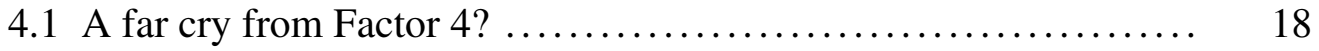

4.2 Total capital value maintained: weak sustainability of a growing economy $\ldots \ldots \ldots \ldots \ldots \ldots \ldots \ldots \ldots \ldots \ldots \ldots, 21$

5 Policy mix and partnership $\ldots \ldots \ldots \ldots \ldots \ldots \ldots \ldots \ldots \ldots \ldots \ldots, 24$

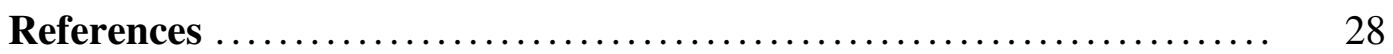




\section{Abstract}

The reductionist trend of equalizing sustainable development with $\mathrm{CO}_{2}$ control needs to be reversed - notwithstanding the significance of climate change. Conventional, 'compartmentalized' data systems impede an integrated vision and treatment of the paradigm. New accounts and balances focus on the interaction between environment and economy. 'Greened' national accounts measure economic sustainability in terms of (produced and natural) capital maintenance; balances of material flows assess ecological sustainability as the dematerialization of production and consumption. Both concepts aim to preserve environmental assets. They differ however with regard to the scope, strength and evaluation of sustainability. First results for Germany indicate weak sustainability of the economy, owing to an increasing capital base. Strong sustainability is not in sight, though, since material throughput has not been reduced sufficiently. An 'Alliance for Sustainable Development' is proposed to implement and sustain the paradigm.

Keywords: Dematerialization; capital maintenance; sustainability; environmental accounting, eco-tax, alliance for sustainable development 


\section{Sustainable development - the great hypocrisy}

The 1992 Earth Summit in Rio de Janeiro produced the magic wand of 'sustainable development' for attaining socioeconomic development while safeguarding the environment. Government, industry and civil society readily embraced the concept. However, the opacity of the concept ${ }^{1}$ rather than genuine consensus is probably the reason for this embracement. Industry sees sustainable development as an opportunity for innovation and new markets; governments proclaim it as a means of soothing 'green' objections to economic growth; and certain groups of civil society use it as a weapon against globalization and merciless competition.

Disillusion spread rapidly five years after the Rio Earth Summit, at the Rio+5 conference. The special session of the United Nations General Assembly achieved at best, in the words of its President Razali Ismail, an "honest appraisal" of meagre progress. ${ }^{2}$ Most governments did not commit to implementing the Summit's Agenda 21 and its conventions. One example are the meagre results of the recent negotiations on the Climate Convention's Kyoto Protocol. The real hypocrisy is revealed, though, in a general 'unwillingness to pay'. Contrary to the North's promises in Rio, new and additional resources for the implementation of Agenda 21 did not come forth (with notable exceptions), and official aid has generally decreased. The Rio Summit's highflying expectations for sustainable development have thus met with disappointment and frustration. Yet, with the advent of the first global summit on sustainable development (Johannesburg, 26 August to 4 September 2002) nobody dares to speak about the unthinkable - the possible demise of the paradigm.

A renewed focus on economic growth, thinly veiled by sustainability rhetoric, reveals indeed a changed perception of sustainable development. Industrialized countries, with the acquiescence of most developing nations, relegate the presumably integrative concept to weak environmental ministries and agencies. At national and international conferences on sustainable development representatives of economic or financial departments are conspicuously absent. 'It's the economy, stupid' ${ }^{3}$ is back on the agenda of growth- and wealth-oriented policy makers.

\footnotetext{
A good example is the popular Brundtland definition of sustainable development as the satisfaction of current and future generations' needs (WCED 1987, p. 43): the definition specifies neither the needs nor the timeframe for their satisfaction, nor a particular role for the environment.

2 See for assessments of the results of Rio+5, Osborn and Bigg (1998).

3 The leitmotiv of former President Bush's election campaign.
} 
Germans, for instance, discovered the stock market and its promise of everincreasing riches with enthusiasm (albeit currently dampened by a world-wide recession). As to environmental concerns, environmental protection is believed to control effectively most emissions, or these concerns are considered a matter of uncertainty like climate change and its long-term effects. Remaining problems ought to be taken care of 'automatically' by the current transition to a non-material knowledge-based service society. ${ }^{4}$ The result is a reductionist view of sustainable development (Box 1), equating development with economic growth, environment with climate change and sustainability with some half-hearted safeguarding against global warming.

Box 1: A reductionist view:

SUSTAINABLE DEVELOPMENT $\Downarrow$

ENVIRONMENTAL POLICY<smiles>[CH]1C=C1</smiles>

CLIMATE

PROTECTION

$\Downarrow$

$\mathrm{CO}_{2}$ control

What is overlooked, of course, is that

- much of the rich countries' environmental successes are achieved on the back of developing nations by depleting their natural resources and exporting dirty industries - in other words by importing sustainability

- services and information technology still require large amounts of energy inputs and material infrastructure, and

- risks of new (notably genetics) and old (nuclear energy) technologies still loom large - as do other concerns such as global nitrogen fertilization, natural disasters, hazardous chemical production, soil degradation and regional wars. ${ }^{5}$

The reductionist trend needs to be exposed and reversed. Otherwise we end up again in the compartmentalization trap where each agency pursues its own idiosyncratic strategy, with the environment languishing on the sidelines. Three steps are essential for facilitating the return of sustainable development to national and international policy agendas. First, the paradigm needs to be operationalized by means of integrative indicators. Second, these indicators should be used in formulating and monitoring sustainability policies. Third, the key players in the sustainability conundrum, i.e. the stake- and shareholders in economic activities, should be brought together in what could be a 'Great Alliance', as suggested in section 5.

4 These Kuznets-curve expectations (discussed and largely refuted in a special edition of Ecological Economics $(25 / 2,1998)$ are usualy not stated explicitly but seem to sustain recent calls in European countries for delaying or abolishing the modest eco-taxes on energy consumption for the sake of economic growth and employment (see also section 5, below).

5 As identified by the United Nations Environment Programme (UNEP) in its GEO-2000 report <www.unep.org/geo2000/english/0250.htm>. 


\section{Unveiling wealth: measuring material throughput and natural capital consumption}

\subsection{Proliferation of indicators}

It is common knowledge that the 'quantitative' measures of economic performance such as the values of production and consumption provide a distorted picture of human wealth and welfare. These measures disregard non-marketed and undesirable side effects of human activity. Early search for alternative indicators of the 'quality' of human life in the 1970s (OECD, 1973) failed, however, in reaching a consensus on the main qualitative elements of human welfare. The results were large and widely differing lists of social indicators which overlapped in scope and coverage, whose significance for assessing human well-being was far from clear, and which used different units of measurement and were thus difficult to compare, aggregate and prioritize (Bartelmus, 1980, pp. 47-50). It is no surprise that these indicator sets were unable to dethrone the leading economic aggregates, GDP, income, employment and consumption, as the main compasses for national policy making.

The late 1980s and 1990s saw a new focus on the negative side of the human quality of life, but this time considering the economic policy causes of environmental degradation and depletion (WCED, 1987). Rather than attempting to measure the unmeasurable, i.e. human happiness or well-being, the idea was to lift the veil of monetary value from economic indicators, notably GDP and its components (Leipert, 1989; Brown, 1993; Daly 1996), to reveal their flaws of

- including 'defensive expenditures' on goods and services that do not contribute to human welfare

- excluding goods and services provided outside the monetized economy

- neglecting (negative) environmental externalities and their social cost, generated by production and consumption

- neglecting inequities in the distribution of environmental impacts, and of income and wealth in general.

These flaws pose indeed a risk of setting the economy on a non-sustainable path of growth and development. After all, economic development is to improve the human standard (or quality) of living. Attempts at capturing all the largely negative social and environmental effects of economic activity created again long 
lists of environmental and sustainability indicators (Bartelmus, 1994b; OECD, 1994; United Nations, 1996; Moldan, Billharz and Matravers, 1997; European Commission, 1999). Of course, these indicators face the same problems of comparability and aggregation as the social indicator sets of 20 years ago.

Other more compound indices sought to convey a broader picture of economic welfare, genuine progress or human development. An eclectic deduction of 'regrettables' (defensive expenditures, environmental externalities, etc.) and addition of 'desirables' (leisure, non-market outputs) and inconsistent concepts, classifications and valuation mixes are major flaws of the Measure of Economic Welfare (Nordhaus and Tobin, 1972), and the Genuine Progress Indicator (GPI) (Cobb, Halstead and Rowe, 1995); the selection of indicators and the equal weighting of unequal and correlated issues by the Human Development Index (HDI) (UNDP, annual) obscure the meaning of this index (Bartelmus, 2001b, p 23).

Two systemic approaches seem now to be more successful in developing integrative measures of the environment-economy interface. They are

- the physical Material Flow Accounts (MFA), developed at the Wuppertal Institute and widely applied in industrialized nations (Bringezu, 1997; Adriaanse et al., 1997; Matthews et al., 2000: Eurostat, 2001) and

- the physical and monetary System of integrated Environmental and Economic Accounting (SEEA) of the United Nations (1993, 2000).

\subsection{Material flow accounting}

The measurement of flows of materials through the economy is to assess the pressure of such throughput on the carrying capacity of natural systems. The approach is based on thermodynamic laws of conservation and entropy of energy and matter. ${ }^{6}$ The MFA make use of these physical laws by applying them to an economic region or political territory like a country. The horizontal view of Figure 1 illustrates how material flows enter the national economy (dotted circle), from the environment and abroad, and leave it as exports and residual 'outputs' of waste and emissions. During a particular accounting period some material inputs may accumulate in long-lasting fixed assets or inventories. This accumulation can be interpreted as - physical — growth of the economy (see section 4.1).

6 It is the merit of Georgescu-Roegen (e.g. 1979) to extend the entropy law beyond energy to matter ("matter matters"), thus providing the rationale for measuring the environment-economy interaction in material and energy flow accounts. 
Figure 1: Environmental (national) accounting and material flows.

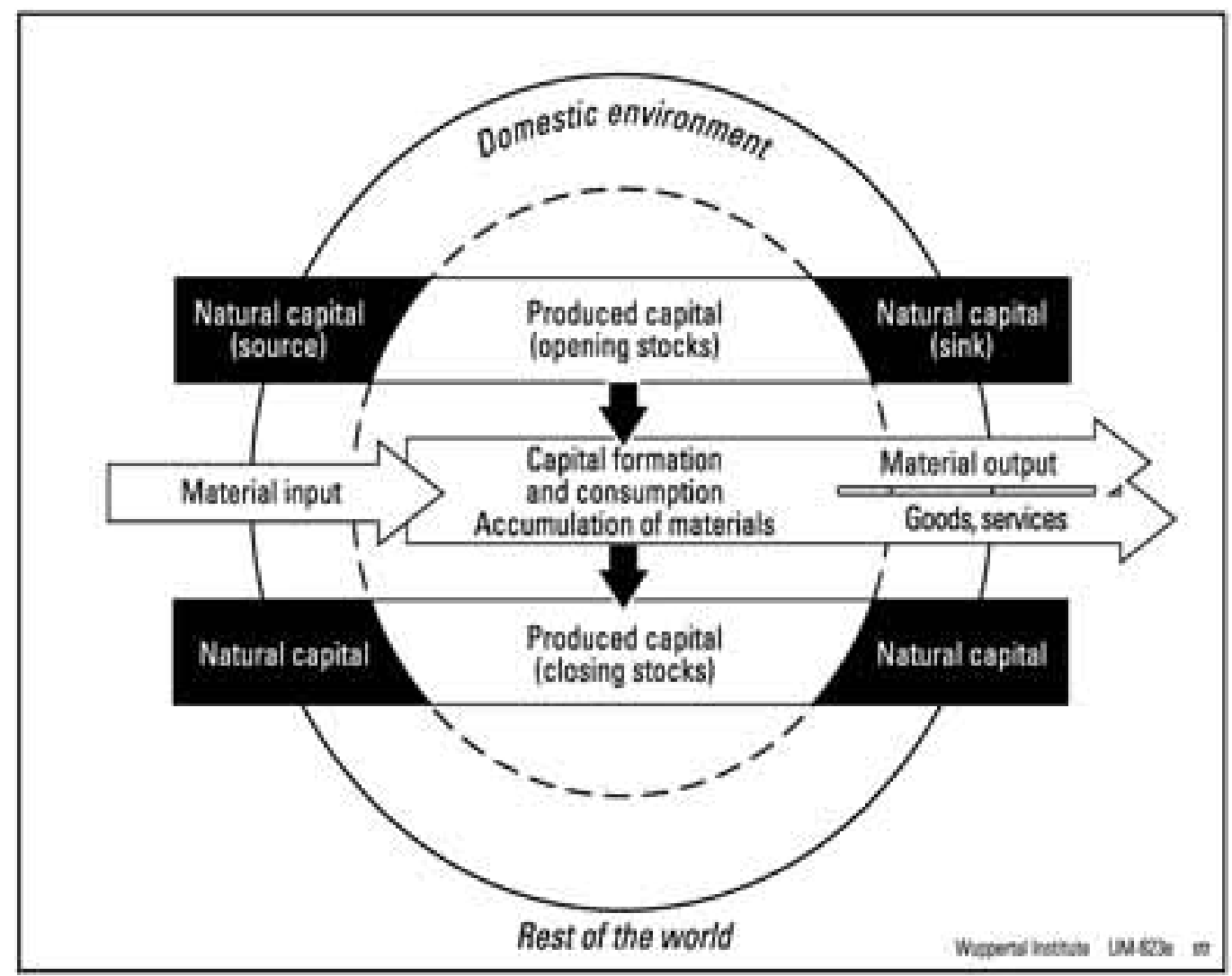

Various indicators of material input and output are to measure the environmental impacts from material throughput (Schmidt-Bleek, 1994; Adriaanse et al., 1997; Matthews et al., 2000). Among others, the MFA assess the Total Material Requirement (TMR) on the input side of material flow balances and the Total Domestic Output (TDO) on the output side. The TMR, in particular, is to measure the overall environmental pressure from natural resource use by adding up the inputs of raw materials in tonnes, including hidden flows or 'ecological rucksacks'. The purpose of such 'weighting by weight' is to capture all kinds of actual and potential environmental impacts and welfare effects. In this manner, a precautionary approach is applied which is to permit anticipation of potentially disastrous and largely unknown environmental effects (Hinterberger et al., 2000).

7 Ecological rucksacks are defined as "the sum of all materials which are not physically included in the economic output under consideration, but which are necessary for production, use, recycling and disposal“" (Spangenberg et al. 1999, p. 15). Other aggregations use area equivalents for assessing environmental pressure on surrounding territories, or even the planet, like the Ecological Footprint (Wackernagel and Rees, 1996) or apply energy units such as the Exergy or Emergy Measures (Odum, 1996). Much of the following argumentation with regard to the use and usefulness of the MFA aggregates applies to these indicators as well. 
On the output side, TDO measures the turnover and distribution (by environmental sink) of total waste and residuals during the accounting period. More importantly — as environmental pressure is already measured by TMR - the selective measurement of particularly noxious substances can be used to assess the 'detoxification' of selected production and consumption processes.

\subsection{Greening the national accounts}

The purpose of material flow accounting is to measure the physical 'metabolism' of the economy (Ayres, 1989) or even the society (Fischer-Kowalski, 1998). Disturbances of this metabolism affect the 'health' of society - literally with regard to human well-being and more generally with regard to the quality of natural systems. Clearly, the 'smooth' functioning of the economy depends on the provision of natural resource flows and environmental services of waste disposal. However, the metabolistic analysis of physical flows cannot by itself make any evaluation of the smoothness of economic performance, unless in extreme cases where a physical breakdown alerts to a corresponding economic one.

It is in fact the very nature of economics to perform such an evaluation, taking scarcities in the availability of raw materials and other factors of production into account and confronting consumer preferences (for goods and services) with the cost of these scarcities. An exclusive focus on the physical basis of the economy treats the economy like an insatiable black hole which gobbles up natural resources and regurgitates these resources as waste and emissions. This may be a natural reaction to the above-described reductionist mood of societies but does not do justice to the evaluative capacity of the economic system. On the other hand, conventional economists have holed up in their own hole by considering nonpriced environmental impacts as an 'externality'.

The basic idea of 'greening' the national accounts has therefore been to overcome this mutual black-holing by

- applying the economic accounting concepts and classifications to environmental assets and asset changes in order to mould them into the stock and flow system of the economy, and

- using the compatibility thus achieved to price and cost the physical stocks and flows so as to make them comparable to the economic concepts of income, production and wealth.

To this end, the SEEA was designed as a 'satellite' system of the world-wide adopted System of National Accounts (SNA) (United Nations et al., 1993). 
Counterpart tabulations in different 'versions' of the original SEEA ${ }^{8}$ ensure the comparability of physical and monetary stocks and flows.

The modification of conventional economic accounting indicators sets out from viewing nature as an additional, non-produced production factor. Using up this production factor reduces the availability of natural resource inputs, and the supply of environmental services of safe absorption of waste and pollutants. In analogy to the consumption of produced ('fixed') capital, natural capital consumption can thus be seen as a further cost element which, when ignored, contributes to the non-sustainability of economic performance. The vertical view of Figure 1 illustrates the role of capital consumption as a measure of loss of capital stocks in the balance sheets of the national accounts.

The SEEA extends these accounts by incorporating natural capital assets in the asset accounts and by additionally costing their consumption in the flow (supply and use) accounts. The accounting for natural capital use extends thus the sustainability criterion of costing capital consumption, already built into the conventional indicators of national income, net product and net capital formation, to natural capital. Modified aggregates of Environmentally-adjusted net Domestic Product (EDP), Value Added (EVA), Capital Formation (ECF), Environmental Cost (EC) and wealth in Economic and Environmental Assets (EEA) are the result (Bartelmus, 2001a, Appendix).

Note that such accounting focuses on the immediate interaction between the environment and the economy in terms of natural capital services for production and consumption. Further welfare effects on health and other social (cultural, ethical) values are thus not accounted for since they are difficult to measure and near-impossible to value in money terms at the national level. This is in line with the basic objectives of national accounting, namely to assess economic performance rather than welfare.

8 The so-called London Group of national accountants has been revising the SEEA which is expected to be re-issued in 2002. Unfortunately, the new 'system' seems to have abandoned the original compatibility for a set of difficult-to-link modules and methodologies for physical and monetary accounting. See for the current status of the revision process,

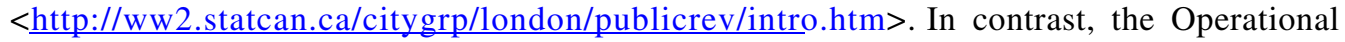
Manual of the SEEA (United Nations, 2000) retains full consistency with the SNA and hence a better capacity for compiling modified 'green' economic indicators. See for a review of the SEEA approach, Bartelmus (2001a). 


\section{Dematerialization versus capital maintenance}

Table 1 gives an overview of the objectives, strategies, measures and policies of two fundamental - ecological and economic - notions of sustainability. Applying the above-described accounting tools to the interface between economy and environment generates operational (quantifiable) concepts of

- ecological sustainability as 'dematerialization' of economic activity, which reduces the pressure on the carrying capacities of natural systems, and

- economic sustainability as 'capital maintenance' which is to ensure continuing economic growth after taking the consumption of both produced and natural assets into account.

\subsection{Dematerialization: attaining ecological sustainability}

Reducing material throughput is to keep the pressure on natural carrying capacities at tolerable levels. The strategy of dematerialization is to decrease raw material inflows into and accumulation within the economy, and outflows of wastes and toxic substances into the environment. Of course, the latter, i.e. the reduction of outflows, can be directly tackled by environmental policy and is therefore added in the table as a supplementary 'detoxification' strategy. The main means of attaining dematerialization is the increase of 'resource productivity', measured in particular by the ratio of GDP over TMR. It is generally held that such technological improvement of the 'eco-efficiency' of production needs to be supported by greater 'sufficiency' in consumption in order to avoid or reduce rebound effects from efficiency gains: Lower costs and prices can be expected to stimulate production and consumption through savings in resource use (Sachs, 1995).

Standards or norms introduce ecological sustainability criteria into the dematerialization analysis by asking: how much pressure is tolerable? They specify permissible levels of the use of materials in economic activity. Best known is probably the Factor 4 standard (von Weizsäcker, Lovins and Lovins, 1997) which calls for halving total material input into the economy while doubling wealth and welfare. At the global level, Factor 4 is derived from the goal of long-term ecological equilibrium of the planet. Planetary equilibrium in turn is operationalized by the normative concept of 'environmental space', defined as equal access to environmental services by everybody (Weterings and Opschoor, 1992). Under current production and consumption patterns, Factor 4 can be 
translated into a Factor 10 for industrialized countries. The assumption is that an equal environmental space should be reached by all in about 50 years while permitting a limited increase of material use in developing countries (SchmidtBleek, 1994, p. 168).

Factor 4 points to the strategic objective of decoupling the use of materials from - unavoidable or desirable - economic growth. Recent statements by some of the Factor 4 protagonists and by those advocating even higher factors seem to dissociate themselves from the 'double-wealth' part of Factor 4. In their view, Factor 4 is more of a general guard-rail (Hinterberger et al., 2000) or leitmotiv (Bringezu, in prep.) to steer policy makers in the right direction than an actual target for attaining sustainable development.

Table 1: Operational concepts and policies of sustainability

\begin{tabular}{|c|c|c|c|}
\hline & \multirow{2}{*}{$\begin{array}{l}\text { Ecological } \\
\text { sustainability: } \\
\text { dematerialization/ } \\
\text { detoxification }\end{array}$} & \multicolumn{2}{|c|}{$\begin{array}{c}\text { Economic } \\
\text { Sustainability }\end{array}$} \\
\hline & & $\begin{array}{l}\text { produced and natural } \\
\text { capital maintenance }\end{array}$ & non-declining welfare \\
\hline Rationale & $\begin{array}{l}\text { Reducing throughput } \\
\text { below carrying } \\
\text { capacities }\end{array}$ & $\begin{array}{l}\text { Sustaining economic } \\
\text { growth }\end{array}$ & $\begin{array}{l}\text { Sustaining qualitative } \\
\text { development }\end{array}$ \\
\hline Strategy & $\begin{array}{l}\text { Decoupling economic } \\
\text { growth from } \\
\text { environmental pressure }\end{array}$ & $\begin{array}{l}\text { Maximizing economic } \\
\text { growth while keeping } \\
\text { produced and natural } \\
\text { capital intact }\end{array}$ & $\begin{array}{l}\text { Maximizing quality of } \\
\text { life }\end{array}$ \\
\hline $\begin{array}{l}\text { Accounting } \\
\text { tools }\end{array}$ & $\begin{array}{l}\text { Material Flow Accounts } \\
\text { (MFA), Physical Input- } \\
\text { Output Table (PIOT) }\end{array}$ & $\begin{array}{l}\text { System for integrated } \\
\text { Environmental and } \\
\text { Economic Accounting } \\
\text { (SEEA) }\end{array}$ & (ad hoc compilation) \\
\hline Key indicators & $\begin{array}{l}\text { TMR, TDO, resource } \\
\text { productivity: } \\
\text { GDP/TMR }\end{array}$ & $\begin{array}{l}\text { 'Green' economic } \\
\text { aggregates: EDP, EVA, } \\
\text { ECF }\end{array}$ & GPI, HDI \\
\hline $\begin{array}{l}\text { Strength of } \\
\text { sustainability }\end{array}$ & $\begin{array}{l}\text { Strong: reduction of } \\
\text { material flows to meet } \\
\text { sustainability standards }\end{array}$ & $\begin{array}{l}\text { Weak: overall capital } \\
\text { maintenance with } \\
\text { substitution between } \\
\text { produced and natural } \\
\text { capital }\end{array}$ & $\begin{array}{l}\text { (not defined, beyond } \\
\text { generic management } \\
\text { rules) }\end{array}$ \\
\hline $\begin{array}{l}\text { Policy } \\
\text { instruments }\end{array}$ & $\begin{array}{l}\text { Regulation and standard } \\
\text { setting (Factor X), fiscal } \\
\text { disincentives for } \\
\text { material inputs, support } \\
\text { to materialsaving } \\
\text { innovation }\end{array}$ & $\begin{array}{l}\text { Use of green indicators } \\
\text { and variables in economic } \\
\text { analysis and policy; } \\
\text { market instruments of } \\
\text { environmental cost } \\
\text { internalization }\end{array}$ & $\begin{array}{l}\text { (spreading antigrowth } \\
\text { sentiment) }\end{array}$ \\
\hline
\end{tabular}


Factor 4 points to the strategic objective of decoupling the use of materials from - unavoidable or desirable - economic growth. Recent statements by some of the Factor 4 protagonists and by those advocating even higher factors seem to dissociate themselves from the 'double-wealth' part of Factor 4. In their view, Factor 4 is more of a general guard-rail (Hinterberger et al., 2000) or leitmotiv (Bringezu, in prep.) to steer policy makers in the right direction than an actual target for attaining sustainable development.

\subsection{Economic sustainability: maintaining growth and welfare}

Environmental economists have investigated the welfare relevance of environmental protection expenditures and environmental degradation and destruction in models of optimal (maximum) economic growth. They define sustainable development as non-declining welfare (or constant per-capita consumption as a measure of inter-generational equity), taking environmental damage and loss of natural resources into account (Solow, 1974; Hartwick, 1977; Dasgupta and Mäler, 1991). However, these abstract notions and models stand little chance of implementation. More practical-minded scholars resorted to simpler indices of economic welfare or human development. As discussed above, even the indices face insurmountable problems of welfare and damage measurement and valuation. Table 1 indicates (in the last column) that these indices fail in supporting concrete policy measures beyond alerting to some deviation between presumed well-being and economic growth. In the words of the GPI authors the objective is to "blast away the obfuscating polemics of growth - and the devious politics that go along with it" (Cobb, Halstead and Rowe, 1995, p. 72).

Rather than assessing damage and utility from economic activity, environmentaleconomic accounting focuses on the cost side of the environment-economy interaction. Economists consider the accumulation of real (non-financial) capital as the 'engine' of economic growth. This engine drives future production and consumption and needs to be repairment and replacement to sustain economic activity. This is because capital stocks are used up in production and ultimately disposed of as waste. Only part of these changes in stocks, namely their permanent loss, beyond repair and regeneration, is considered as non-sustainable and therefore costed as capital 'consumption' in the SEEA. Economic sustainability is thus simply the extension of the conventional economic notion of long-term capital maintenance to natural assets. In this manner, future growth potentials are more accurately determined, since the cost of natural capital destruction is accounted for. Environmentally-adjusted (net) capital formation (ECF) indicates thus a nation's ability to generate new capital, and hence future growth, after taking produced and natural capital consumption into account. 
At the micro-economic level of households and enterprises, future environmental impacts could be avoided or mitigated by budgeting additionally for the cost of natural capital consumption and using these cost allocations for capital replacement. 'Market instruments' (eco-taxes, effluent charges, tradable-emission and natural-resource-use permits, environmental protection subsidies) are to bring about such 'cost internalization' and spending by economic agents. At the same time, governments might use the revenues from these instruments for investments in natural capital increase or enhancement (see Box 3, below).

\subsection{A physical-monetary dichotomy}

The focus on physical targets and indicators by environmentalists on the one hand, and on full-cost (including environmental costs) pricing and investment by economists has unfortunately given rise to a highly charged dispute between the two camps. The roots of this dissent lie in a different world-view of economists and environmentalists. ${ }^{9}$ Economists rely on individual preferences, expressed or simulated in markets (and market prices) to value economic products and environmental assets and services. In contrast, environmentalists consider the environment as an indivisible (public) good on whose value markets should not have say.

The physical-monetary dichotomy is also present in the accounting systems and can therefore be investigated in more operational terms. Table 1 presents this dichotomy with the MFA and the physical input-output tables (PIOT) on the physical side and the SEEA and welfare indices on the monetary side. ${ }^{10}$

Both MFA and SEEA, and their respective concepts of dematerialization/ detoxification and capital maintenance, deal with the input and output sides of material flows. The MFA remain however in the physical assessment stage, whereas the SEEA changes physical units into cost, in accordance with national accounts conventions. Does this mean that their physical and monetary assessments are two sides of the same sustainability coin?

At the most generic level, dematerialization and capital maintenance appear indeed to have a similar sustainability objective: namely the long-term

\footnotetext{
9 This crude distinction betweeen environmentalist views of the human environment and mainstream (neoclassical) economic approaches to the environment-economy interface is, of course, a simplification of existing schools of thought. For instance, "ecological economists" can be placed somewhere in between. See for a more detailed discussion of the polarization of ecological and environmental economists, Bartelmus (2000).

${ }^{10}$ Note that the SEEA, and in particular its revised draft version, also account fully for their physical counterparts. PIOTs, which include flows of materials and pollutants, were pioneered in Germany (Stahmer, Kuhn and Braun 1998).
} 
preservation of environmental assets and their source and sink functions. Their measures differ, however, when looking more closely at their definition, scope and envisaged uses. Besides more technical deviations of MFA categories from SNA/SEEA standards and definitions (Bartelmus with Vesper, 2000), dematerialization

- appears to be less integrative, with regard to the environment-economy interface, than capital maintenance: It has to resort to calculating ratios of resource productivity or material intensity, whereas green accounting indicators (EDP, ECF) subtract directly environmental cost from conventional economic aggregates

- evaluates environmental impacts and sets corresponding policy priorities 'exogenously' by governmental or expertocratic fiat as sustainability standards, notably Factor X. Such normative evaluation is avoided in principle by environmental costing, since the deduction of these costs obtains simply a 'netter' value of production, without double-counting (depreciation) costs ${ }^{11}$

- implies intra- and inter-generational equity of equal access to environmental services by the present and future generations, as a consequence of such standard setting, whereas natural capital valuation discounts future capital uses according to the preferences of the current generation's investors ${ }^{12}$

- combines the impacts caused directly by activities of a particular nation with those caused indirectly through imports (and hence borne by other nations). This permits the assessment of total physical pressure from the supply and demand side of economic activity; in contrast, the rigorous 'cost' definition of the national accounts applies a strict cost-caused concept to avoid doublecosting and inconsistent valuation mixes when summing up environmental impacts

- is easier to measure and interpret than environmental cost and environmentally-adjusted economic indicators. But such ease has its price: While depletion and degradation costs represent the — non-sustainable — permanent loss of natural capital, MFA indicators do not allow for the regeneration of natural resources and absorptive sinks

- is more anticipatory: adding up material inflows and movements is a precautionary approach which alerts to actual and potential, and in fact

11 Note however that the more practical (than damage valuation) maintenance costing of the SEEA has sometimes to resort to costing the compliance with environmental quality standards (as proposed by Baumol and Oates, 1971). This is the case when total avoidance costing would lead to excessive - as compared to economic benefits of a production or consumption process - cost levels.

12 Notably when calculating the 'net present value' of natural resource stocks. See for a discussion of the different valuation techniques applied in environmental accounting, Bartelmus (1998). 
frequently unknown, environmental impacts which in the final analysis are all the result of natural resource exploitation. This is also the justification for using a 'directionally safe' (towards sustainable development) aggregate obtained by a relatively crude weighting by weight of environmental impacts.

Dematerialization and capital maintenance: two sides of the same coin? The answer is 'yes', but only as far as the most generic goal of environmental sustainability is concerned. Otherwise, there are important differences in the scope of the sustainability concept, the strength of the underlying sustainability notions, the implied environmental risk assessment, the evaluation (weighting) of environmental impacts, and pertinent strategies and policies. Both notions also focus on the sustainability of economic performance or growth, at the expense of further social and institutional dimensions of a sustainable development concept. Sustainable development would have to be defined in terms of a normative framework for non-economic goals of development (Bartelmus 1994a, p. 73).

The following is to illustrate and evaluate these generic arguments by applying the assessment tools of MFA and SEEA to Germany. 


\section{Germany: a sustainable economy?}

\subsection{A far cry from Factor 4 ?}

As already mentioned, the purpose of reducing material flows is to delink economic growth from material consumption and hence from its environmental impacts. Figure 2 plots the changes of TMR per capita against growth of GDP per capita for selected countries and mostly for a 20-year period (1975-1994). This is to link (de)materialization of the respective economies to their different economic developments. TMR per capita seems to be levelling off for the industrialized countries at about 80 tonnes per annum, except for Japan, at 40 tonnes, due to its low energy consumption. Low TMR in Poland and China reflects these countries' relatively low levels of economic development. Upward-pointing arrows indicate that these (and probably other developing and transition countries) might well catch up with the high-material-intensity economies of industrialized nations. In general, while there seems to be some relative delinkage ${ }^{13}$ from growing GDP, all these economies are still a far cry from dematerializing in absolute terms and by the desirable sustainability standards of Factors 4 or 10.

13 Note that relative dematerialization, i.e. declining material intensity, expressed in TMR per GDP could still permit an increase of total material use with growing GDP. 
Figure 2: Material use and economic growth in selected countries ${ }^{a)}$

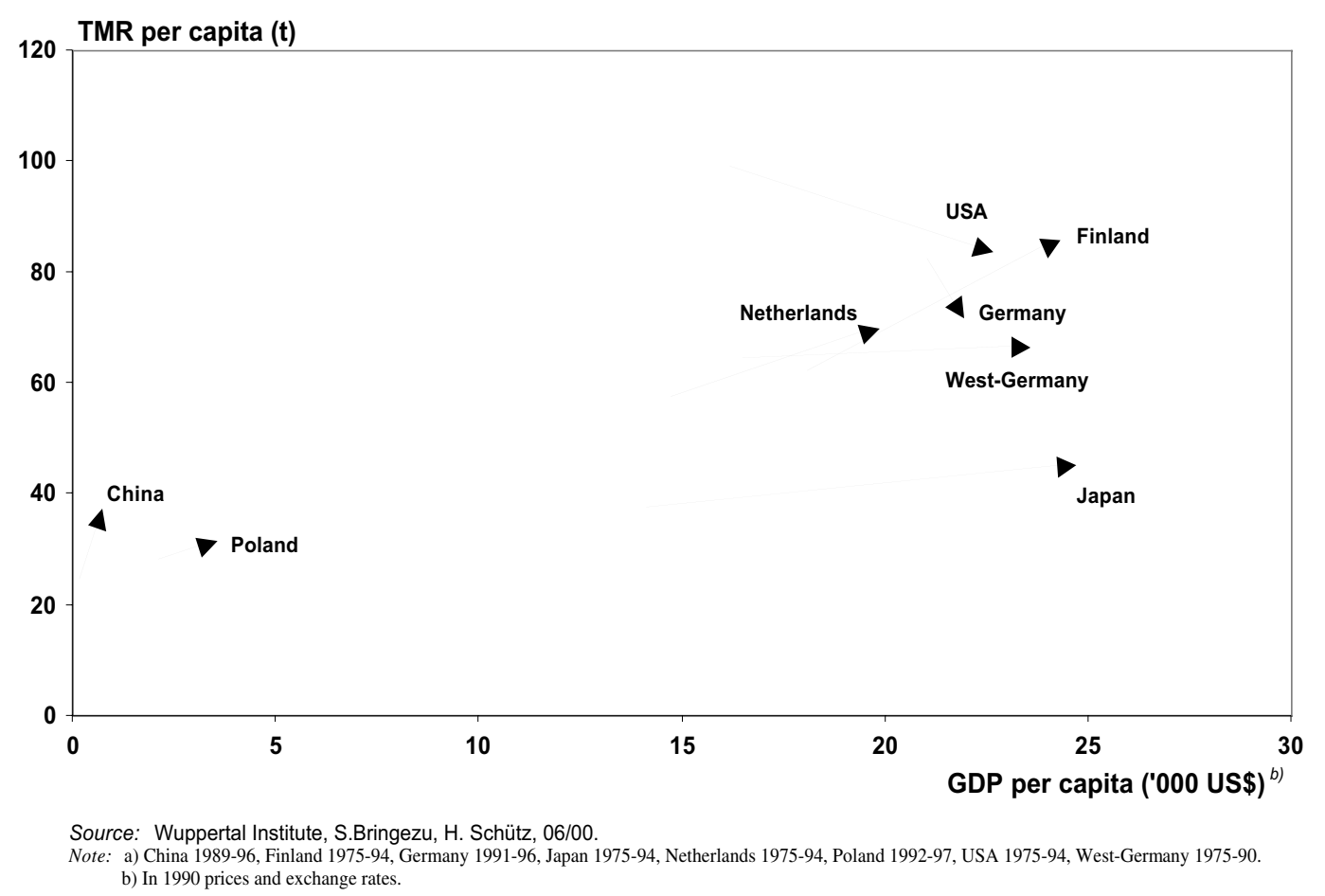

Germany seems to be an exception. Recent numbers indicate an absolute decrease (steep downward arrow) in TMR per capita from about 80 tonnes in the early 1990s to 72 tonnes in 1996. The main reason is the decrease of overburden resulting from the closure of unprofitable lignite mines in the new States (neue Länder) after the country's reunification. Converging arrows of Germany and West-Germany indicate that West-Germany's production and consumption patterns and concomitant constant material use might soon prevail.

Figure 3 shows the influence of reunification once more by the dotted-line jump of TMR (1991/1992) from 4.5 to 7 billion tonnes. The figure also shows the huge blow-up of material use (as the difference between direct material input, DMI, and TMR) if hidden 'ecological rucksacks' are accounted for. Over time there seems to be little difference in the development of DMI and TMR. Much of the hidden flows consist of the rucksacks generated by production in other countries, whose outputs were imported by Germany (Bringezu, 1997). At least part of Germany's economic growth seems thus to have been facilitated by importing sustainability, possibly also from developing countries. 
Figure 3: Material requirement, Germany 1975-96

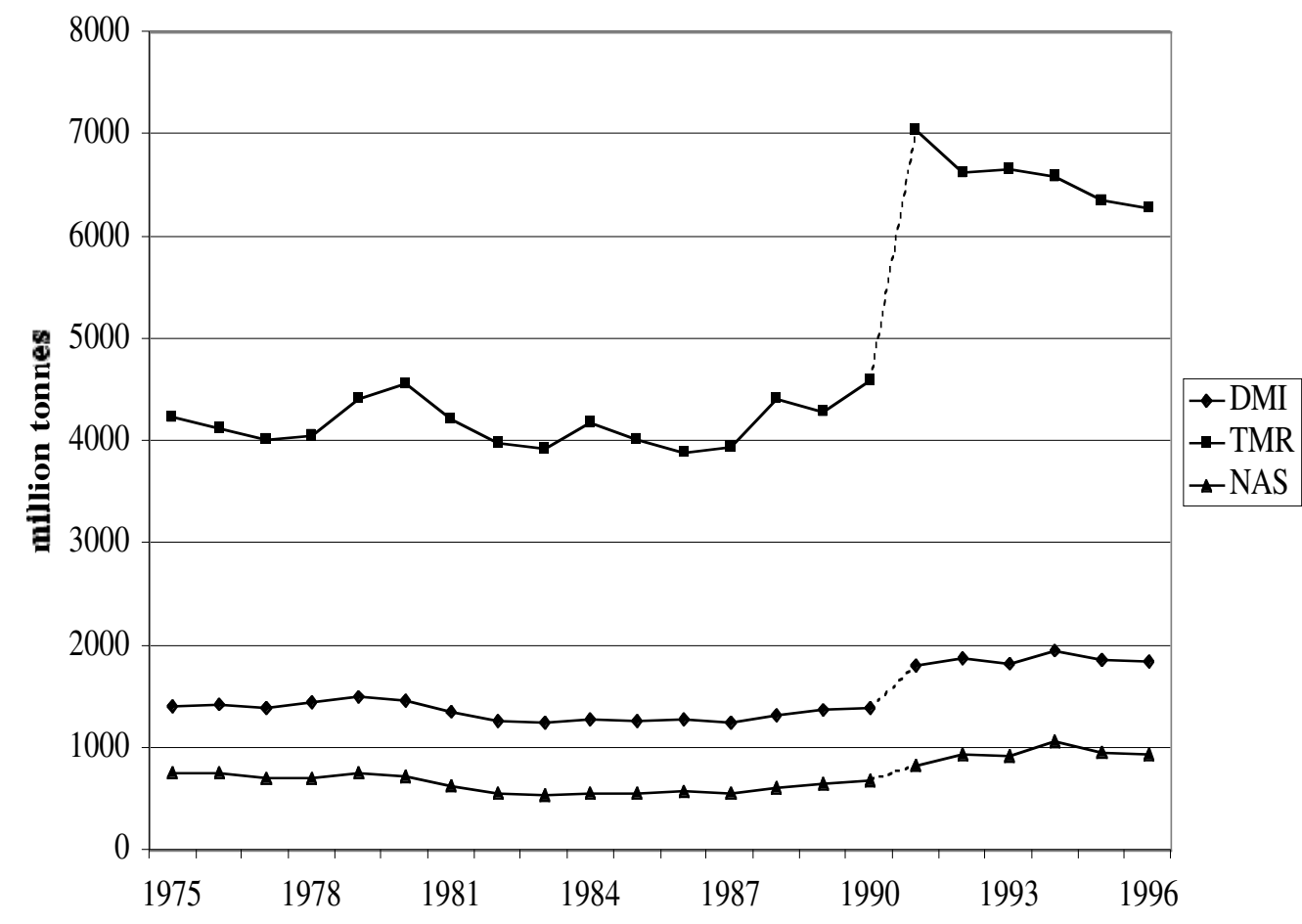

Source: Wuppertal Institute, S. Bringezu, H. Schütz, 01/01.

Figure 3 also presents net additions to stock (NAS), hovering first below and then, for unified Germany, at, one billion tonnes. NAS represent the materials stored in durable goods such as buildings and infrastructure. Such accumulation of materials in the economy can be interpreted as a measure of the - physical growth of the economy. On its own, just as its opposite, the wear and tear of fixedassets, this accumulation cannot be kept up in the long term (Bringezu, 2000, pp. 59-60). Daly (1996, p. 32) considers therefore a constant aggregate throughput (where input equals output) as the defining feature of a "steady-state economy". Obviously such an economy would still have to specify normative limits to throughput in order to attain ecological sustainability or dematerialization by a certain Factor X.

The economic meaning of NAS is less clear. It reflects to some extent increasing land use through built-up areas, though land use is probably better measured by areal statistics. In principle, the indicator represents the physical counterpart of net capital formation which has moved up more or less in line with GDP by about 10\% (1991-1999, in constant prices) in unified Germany (Statistisches Bundesamt, 2000). The resulting scissor movement of NAS and capital formation can be taken as a qualitative improvement of capital, resulting from technological progress in capital productivity: capital goods seem to have received higher values 
(per tonne) in the markets because of their capability to increase output with the same volume of capital goods. Again, conventional productivity analysis seems to be more appropriate to assess technological progress.

\subsection{Total capital value maintained: weak sustainability of a growing economy}

Productivity numbers can be quite misleading, however, if they do not take into account, in their numerator, the reduction of bads, i.e. the successful reduction of pollution, together with the goods of economic output. For instance, estimates of the World Resources Institute showed that productivity of the electric utility sector declined by about $0.38 \%$ annually but, corrected for emission reduction, productivity actually rose by the same amount (Repetto, 2001, pp. 113/114).

Moreover, as described above, the neglect of natural capital consumption has rendered the indicators of economic growth, net domestic product (NDP) and net capital formation (NCF), misleading with regard to a nation's long-term growth potential. The additional costing of natural capital consumption and reinvestment of this cost caters thus to the economic notion of sustainability. Upward trend of a 'truly net' (deducting environmental costs of natural capital consumption from NDP) domestic product, i.e. EDP, would therefore indicate the environmental and economic sustainability of economic growth.

Table 2 presents first estimates from a pilot SEEA study for Germany, prior to (1990) and after $(1991,1995)$ unification. EDP estimates for three years (and moreover in current prices) obviously cannot assess any trends in the environmental sustainability of economic growth. Still, Table 2 shows a distinct increase of environmental costs from about 60 billion DM (about 3\% of NDP) in 1990 to 83 billion DM (3.3\% of NDP) in 1991 because of the coverage of the new States in 1991. Thereafter, adaptation of the new States to West-Germany's modern production methods appears to have removed the cost increase by 1995 . The table also identifies agriculture and energy supply as the most environmentalcost-intensive industries (per unit of value added) - costs that consist largely of pollution, since natural resource depletion is of little importance in Germany. 
Table 2: Environmental and green accounting indicators

(Germany 1990, 1991 and 1995)

(provisional estimates)

\begin{tabular}{|c|c|c|c|c|c|c|}
\hline & \multirow{2}{*}{ Total } & \multicolumn{3}{|c|}{1990} & 1991 & 1995 \\
\hline & & $\begin{array}{l}\text { Agriculture, } \\
\text { fishery and } \\
\text { forestry }\end{array}$ & $\begin{array}{c}\text { Iron and } \\
\text { steel }\end{array}$ & $\begin{array}{l}\text { Energy } \\
\text { supply }\end{array}$ & & \\
\hline NDP (billion DM) & 1943 & 24.8 & 14.4 & 39.6 & 2527 & 3002 \\
\hline EDP (billion DM) & 1884 & 16.6 & 11.7 & 26.3 & 2444 & 2926 \\
\hline$E C / N D P(\%)$ & 3.0 & 33.4 & 18.9 & 33.6 & 3.3 & 2.5 \\
\hline$N C F / N D P(\%)$ & 11.1 & & & & 12.0 & 9.2 \\
\hline$E C F / N D P(\%)$ & 8.1 & & & & 8.7 & 6.7 \\
\hline
\end{tabular}

Source: Bartelmus (2001b) and new calculations.

Explanations: $\quad \mathrm{EC}=$ environmental cost of natural capital consumption; $\mathrm{EDP}=\mathrm{NDP}-\mathrm{EC}$; $\mathrm{ECF}=\mathrm{NCF}-\mathrm{EC}$;

see Bartelmus (2001a) for details on the definition green accounting aggregates.

A more pertinent way of looking into the sustainability of economic performance is to measure a nation's ability to generate new capital after taking produced and natural capital consumption into account. The adjusted capital formation indicator (ECF) reflects such broadened capital consumption by deducting the value of natural capital consumption from net capital formation. ECF remained positive, albeit at lower levels than the conventional NCF indicator, indicating a net growth in the overall value of (natural and produced) capital. Germany's economic performance during the few years covered can thus be considered 'weakly' sustainable, assuming that lost natural capital can be replaced by other produced, human or renewable-natural capital categories. In case of complementarities, i.e. use and abuse of irreplaceable (non-sustainable) natural assets, reinvestment cost into compensating production and consumption activities, e.g. through evasion or health expenditures within Germany or through import of sustainability, could be much higher.

The good news is that the avoidance or immediate mitigation costs of environmental impacts are relatively low at three per cent of net product; the bad news is that actual and potential (future) damage from these impacts could be considerably higher. As mentioned earlier, such damage cost are near-impossible 
to estimate at the national level. In fact, those brave enough to do so came up with values ranging from about the same as our natural capital consumption value to twenty times this value. ${ }^{14}$

In conclusion, from an ecological point of view, Germany's has not been a sustainable economy. Even if the economic point of view claims weak sustainability, we have to consider that such sustainability carries the risk of hitherto unexplored - complementarities. It is a challenging task for sustainability analyses to assess the existence and magnitude of such complementarities for an economy, and not just for a few production and consumption processes. First modelling exercises indicate that, under particular assumptions, even ecological sustainability can be reached. ${ }^{15}$. Is Germany's economy sustainable? The answer is: hardly so in the past, but possibly in the future (Bartelmus, 2001b, p. 33).

14 See for environmental damage estimates: (1) for Germany, Wicke (1993, pp. 60 et seq. and 114) and (2) for the EU, Markandya and Pavan (1999, p. 129).

15 One such model is a dynamic input-output analysis which indicated, that - under quite restrictive assumptions about production and consumption functions, price formation, and social and ecological standards - Factor-10 sustainability can be attained in Germany, and without major losses in economic growth (Hans-Böckler-Stiftung, 2000). 


\section{$5 \quad$ Policy mix and partnership}

The remaining question is, what do the obviously different notions and assessments tell us for drawing strategic and policy conclusions?

Dematerialization strategies set physical standards to make the connection with sustainability in economic growth and development. They envision the imminent transgression of ultimate planetary limits, with irreparable damage to the environment and increasing strife for natural resources. As a consequence, the ecological (non)sustainability point of view conveys a sense of urgency for tackling the environmental problem.

The goal of overall capital maintenance for ensuring continuing economic growth does not deny the existence of environmental problems. It seeks, however, to weigh environmental damage from, against economic benefits of, such growth. 'Economic instruments' are deemed to be the key for bringing about environmentally sound production and consumption patterns. Optimism about the ability of restrained market forces to find "optimal" solutions to trade-offs between economic benefits and environmental quality characterizes the economic view of sustainability.

The essential difference between the two strategic visions lies thus in the evaluation of our closeness to environmental limits. Obviously this opens the field to rhetoric and polemics until better and widely accepted empirical assessments pave the way to consensus. In the meantime we should pursue both strategies, determine heuristically a particular policy mix and monitor closely the sucesses or failures of these policies.

A first step toward the implementation of physical dematerialization standards are so-called 'management rules' for sustainable development (Daly, 1990). They include

- lowering the scale of throughput to levels of natural carrying capacities

- use of renewable resources within regeneration rates

- replacing, where possible, consumption of non-renewable resources by equivalent renewable ones, and

- use of natural sinks within their absorptive and regenerative capacities. 
In practice, these generic rules have at least partially been translated by governmental fiat into specific standards. Box 1 lists such standards for Germany's 'environmental barometer', which is part of a draft national environmental policy programme. It remains to be seen to what extent these standards will be implemented by environmental regulation, which comes naturally to those favouring ecological sustainability, or by more flexible policy instruments, advocated by mainstream (environmental) economists.

\section{Box 2: Environmental barometer Germany — indicators and targets}

Climate:

- annual $\mathrm{CO}_{2}$ emission - 25\% reduction of 1990-level by 2005

Air quality:

- emission of $\mathrm{SO}_{2}, \mathrm{NO}_{\mathrm{x}}, \mathrm{NH}_{3}$ and VOCs - 70\% of 1990-levels by 2010

Land use:

- increase of infrastructural use - reduction to 30 ha per day by 2020

- ecological priority area - safeguarding 10-15\% of non-settled area by 2020

Water quality:

- adsorptive organic halogen compounds in rivers $-<25 \mu \mathrm{g} / \mathrm{l}$ by 2010

- total N-loading — <3mg/l by 2010

Natural resources:

- GDP/primary energy consumption - doubling of 1990 level by 2020

- GDP/consumption of non-renewable resources - increase of 1993 level by Factor 2.5 by 2020

Source: Bundesumweltministerium (1998), p. 33

Germany's draft policy programme (proposed by the previous government) leans toward the latter, i.e. towards voluntary agreements and market forces, reined in by instruments of environmental cost internalization. Market intervention ought to be minimized by allocating environmental costs to those who cause them. The level and allocation of these costs to causing agents is left open as it is indeed difficult to measure the physical environmental impacts and to value these impacts as damages or avoidance - the very purpose of an integrated national accounting system. 
In the absence of such accounting, and in fact opposition to compiling environmentally-adjusted economic aggregates, ${ }^{16}$ market instruments are generally set according to political exigencies. In Germany (and other European countries) the result has been a heated discussion, accompanied by widespread protests against an eco-tax which supposedly exceeded the 'Schmerzgrenze' (limit of pain tolerance) for income losses. It is difficult to see, though, how one can change production and consumption patterns without some painful incentive to do so. Giving in to all kind of non-ecological pressures because of lack of factual (quantitative) information may indeed change the purpose of a well-intended environmental tax (see Box 3).

\section{Box 3: How ecological is Germany's eco-tax?}

- Tax rate differentiation and exemptions (notably for lignite) for the consumption of different energy carriers caters to social and economic objectives (financing social security, supporting regional economic growth) rather than tackling emissions and their effects.

- Exemptions for high energy consumers distort the allocation of environmental cost, at the expense of small-scale energy uses and users, and disregard emission potentials of different energy carriers.

- Annual estimated eco-tax revenues of about 20-30 billion DM in the next few years are way below the environmental cost estimates shown above. This points to a massive underestimation of the necessary tax rate.

- There is no clear concept, apart from (mis)appropriation for economic and social purposes, of tax revenue uses. Given the inherent underestimation of environmental cost and time-lagged effects of cost internalization (facing possible 'irreversibilities'), their use in environmental protection can be justified.

Faith in technology for increasing natural resource as well as natural capital productivity provides some common ground between dematerialization and capital maintenance strategies. Resource productivity focuses, however, on material inputs (e.g. by trading material use certificates) whereas capital maintenance tackles resource depletion and environmental degradation, in particular by fiscal disincentives. It makes sense, indeed, to address sustainability from both the input and the output sides. Care should be taken, however, that the

16 Notably by 'official' statisticians, e.g. Schöhr (2001, p. 40): “There won't be a green GDP”. 
pliers of reducing material inputs and residual outputs do not cut off much needed global economic development, e.g. by an exaggerated quest for self-sufficiency or autarchy in natural resource use. A 'cradle-to-grave' management of production and consumption processes has its undeniable benefits at the micro-level of enterprises and households but might not necessarily apply at national or global levels. Neither will technology alone be the saviour, especially if gains in resource use and pollution are offset by increased consumption. As already mentioned, eco-efficiency in production would have to be supplemented by some kind of consumptive restraint.

As the eco-tax dispute shows, new production patterns and lifestyles cannot be imposed single-handedly by governmental fiat, but require the collaboration of all actors involved. Considering also that unfettered markets, as well as the abovedescribed accounting systems, are not capable of taking non-economic dimensions of sustainability into account, the need for a political dialogue becomes evident. This dialogue should include all shareholders, benefiting from economic activity, and stakeholders, suffering from its environmental, social or cultural effects. Germany's Bündnis für Arbeit (Alliance for Work) between government, corporations and trade unions looks like a model to be extended into the field of environment. ${ }^{17}$ A Great Alliance for Sustainable Development could be the result - great because it should cover all dimensions of sustainability and would also provide a platform for achieving consensus, partnership and commitment among all share- and stakeholders of economic development. The sustained implementation of sustainable development may depend on it.

17 A recent attempt at creating an 'Alliance for Work and Environment' (Friedrich-Ebert-Stiftung et al., 2000) is not very promising since it appears to exclude industry as a key economic player, as well as other social consumer and stakeholder groups. 


\section{References}

Adriaanse, A. et al. (1997), Resource Flows: The Material Basis of Industrial Economies, Washington, D.C.: World Resources Institute.

Ayres, R.U. (1989), 'Industrial metabolism', in: J. Ausubel and H. Sladovich (eds.), Technology and Environment, Washington, D.C.: National Academy Press.

Bartelmus, P. (1980), Economic Development and the Human Environment, Munich and London: Weltforum Verlag.

Bartelmus, P. (1994a), Environment, Growth and Development - The Concepts and Strategies of Sustainability, London and New York: Routledge.

Bartelmus, P. (1994b), Towards a Framework for Indicators of Sustainable Development, DESIPA Working Paper Series No. 7, New York: United Nations.

Bartelmus, P. (1998), 'The value of nature: valuation and evaluation in environmental accounting', in: K. Uno and P. Bartelmus (eds.), Environmental Accounting in Theory and Practice, Dordrecht, Boston and London: Kluwer Academic Publishers.

Bartelmus, P. (2000), 'Sustainable development: paradigm or paranoia?', International Journal of Sustainable Development 3, 358-369.

Bartelmus, P. (2001a), 'Accounting for sustainability: greening the national accounts', in: M.K. Tolba (ed.), Our Fragile World, Forerunner to the Encyclopedia of Life Support Systems, Vol. II, Oxford: Eolss Publishers.

Bartelmus, P. (2001b), 'Zur Rolle neuer Indikatoren in Nachhaltigkeitsmessung und -analyse' [The role of new indicators in the assessment of sustainability], in: P. Bartelmus (ed.), Wohlstand entschleiern — über Geld, Lebensqualität und Zukunftsfähigkeit, Stuttgart and Leipzig: Hirzel [Unveiling wealth — on money, quality of life and sustainability, English translation, in prep.].

Bartelmus, P. with A. Vesper (2000), Green Accounting and Material Flow Analysis Alternatives or Complements?, Wuppertal Papers No. 106, Wuppertal Institute for Climate, Environment and Energy.

Baumol, W.J. and W.E. Oates (1971), 'The use of standards and prices for protection of the Environment, Swedish Journal of Economics 73, 42-54.

Bringezu, S. (1997), 'From quantity to quality: materials flow analysis', in S. Bringezu, M. Fischer-Kowalski, R. Kleijn and V. Palm (eds.), Regional and National Accounting: From Paradigm to Practice of Sustainability, proceedings of the ConAccount workshop, 21-23 January, 1997, Leiden, The Netherlands, Wuppertal Special 4.

Bringezu, S. (2000), 'Material flow analyses for sustainable resource management in Germany and Europe', background paper for the SCOPE Workshop on Material Flow Analysis for Sustainable Resource Management (Wuppertal, 23-24 November 2000).

Bringezu, S. (in prep), Aspects of Sustainable Resource Management in the European Union, Wuppertal Papers, Wuppertal Institute for Climate, Environment and Energy. 
Brown, L.R. (1993), 'A new era unfolds', in L.R. Brown et al. (eds)., State of the World 1993 - A Worldwatch Institute Report on Progress Toward a Sustainable Society, London and New York: Norton.

Bundesumweltministerium (1998), Nachhaltige Entwicklung in Deutschland, Entwurf eines umweltpolitischen Schwerpunktprogramms [Sustainable development in Germany, draft environmental priority programme], Bonn: Bundesministerium für Umwelt, Naturschutz und Reaktorsicherheit.

Cobb, C., T. Halstead and J. Rowe (1995), 'If the GDP is up, why is America down?', The Atlantic Monthly, October 1995, 59-78.

Daly, H.E. (1990), Towards some operational principles of sustainable development', Ecological Economics 2, 1-6.

Daly, H.E. (1996), Beyond Growth, Boston: Beacon Press.

Dasgupta, P. and K.-G. Mäler (1991), The Environment and Emerging Development Issues, Beijer Reprint Series No. 1, Stockholm: Beijer.

European Commission (1999), Towards a European Set of Environmental Headline Indicators (draft).

Eurostat (2001), Economy-wide Material Flow Accounts and Derived Indicators, A Methodological Guide, Luxembourg: European Communities.

Fischer-Kowalski, M. (1998), 'Society's metabolism, the intellectual history of material flow analysis, part I, 1860-1970', Journal of Industrial Ecology 2 (4), 107-136.

Friedrich-Ebert-Stiftung, Hans-Böckler-Stiftung, Deutscher Gewerkschaftsbund und Deutscher Naturschutzring (eds.) (2000), Bündnis für Arbeit und Umwelt [Alliance for Work and Environment], Bonn: Friedrich-Ebert-Stiftung.

Georgescu-Roegen, N. (1979), 'Energy analysis and economic valuation', The Southern Economic Journal 45, 1023-1058.

Hans-Böckler-Stiftung (ed.) (2000), Wege in eine nachhaltige Zukunft. Ergebnisse aus dem Verbundprojekt Arbeit und Ökologie [The road to a sustainable future. Results of a joint project on labour and ecology], Düsseldorf.

Hartwick, J.M. (1977), 'Intergenerational equity and the investing of rents from exhaustible Resources’, American Economic Review 67 (3), 972-974.

Hinterberger, F., F. Luks, M. Stewen and J. van der Straaten (2000), 'Environmental policy in a complex world', International Journal of Sustainable Development 3, 276-296.

Leipert, C. (1989), 'National income and economic growth: the conceptual side of defensive expenditures', Journal of Economic Issues 23, 843-856.

Markandya, A. and M. Pavan (1999), Green Accounting in Europe — Four Case Studies, Dordrecht, Boston and London: Kluwer Academic Publishers.

Matthews, E. et al. (2000), The Weight of Nations, Material Outflows from Industrial Economies, Washington, D.C.: World Resources Institute.

Moldan, B., S. Billharz and R. Matravers (eds.) (1997), Sustainability Indicators: A Report on the Project on Indicators of Sustainable Development, Chichester and others: Wiley.

Nordhaus, W.D., J. Tobin (1972), 'Is growth obsolete?', Fiftieth Anniversary Colloquium V, New York: National Bureau of Economic Research. 
Odum, H.T. (1996), Environmental Accounting — Emergy and Environmental Decision Making, New York and others: Wiley.

Organisation for Economic Co-operation and Development (OECD) (1973), List of Social Concerns Common to Most OECD Countries, Paris: OECD.

Organisation for Economic Co-operation and Development (OECD) (1994), Environmental Indicators, Paris: OECD.

Osborn, D. and T. Bigg (1998), Earth Summit II, Outcomes and Analysis, London: Earthscan.

Repetto, R. (2001), 'Assessment of Sustainability in Growth and Development. Approaches and Policy Applications', in: P. Bartelmus (ed.), Wohlstand entschleiern, Stuttgart und Leipzig: Hirzel.

Sachs, W. (1995), 'From efficiency to sufficiency', Resurgence 171, 6-8.

Schöhr, K. (2001), 'Das “Ökoinlandsprodukt” wird es nicht geben' [There won't be a green GDP], in: P. Bartelmus (ed.), Wohlstand entschleiern, Stuttgart und Leipzig: Hirzel.

Schmidt-Bleek, F. (1994), Wieviel Umwelt braucht der Mensch?, MIPS, das Maß für ökologisches Wirtschaften, Berlin, Basel und Boston: Birkhäuser.

Solow, R.M. (1974), 'Intergenerational equity and exhaustible resources', Review of Economic Studies, Symposium, 29-46.

Spangenberg, J.H., A. Femia, F. Hinterberger and H. Schütz (1999), Material Flow-based Indicators in Environmental Accounting, Copenhagen: European Environment Agency.

Stahmer, C., M. Kuhn and N. Braun (1998), Physical Input-Output Tables for Germany, 1990, Eurostat Working Paper No. 2/1998/B/1, Luxembourg: Eurostat.

Statistisches Bundesamt (2000), Volkswirtschaftliche Gesamtrechnungen [National accounts], Fachserie 18, Wiesbaden: Statistisches Bundesamt.

United Nations (1993), Integrated Environmental and Economic Accounting, New York: United Nations.

United Nations (1996), Indicators of Sustainable Development, Framework and Methodologies, New York: United Nations.

United Nations (2000), Integrated Environmental and Economic Accounting, An Operational Manual, New York: United Nations.

United Nations et al. (1993), System of National Accounts 1993, New York and others: United Nations and others.

United Nations Development Programme (UNDP) (annual), Human Development Report, New York and Oxford: Oxford University Press.

Weizsäcker, E.U. von, A. Lovins and H. Lovins (1997), Factor Four: Doubling Wealth - Halving Resource Use, London: Earthscan.

Weterings, R. and P. H. Opschoor (1992), The Ecocapacity as a Challenge to Sustainable Development, Netherlands Advisory Council for Research on Nature and Environment (RMNO), Rijswijk.

Wackernagel, M and W. Rees (1996), Our Ecological Footprint, Reducing Human Impact on the Earth, Gabriola Island, BC and Philadelphia, PA: New Society Publishers. 
Wicke, L. (1993), Umweltökonomie [Environmental economics], $4^{\text {th }}$ ed., Munich: Franz Vahlen.

World Commission on Environment and Development (WCED) (1987), Our Common Future, Oxford and New York: Oxford University Press. 